\title{
An Effective Synthesis Method for Tilorone Dihydrochloride with Obvious IFN- $\alpha$ Inducing Activity
}

\author{
Junren Zhang ${ }^{1,2,+}$, Qizheng Yao ${ }^{3, \dagger}$ and Zuliang Liu ${ }^{1, *}$ \\ Received: 9 October 2015 ; Accepted: 26 November 2015 ; Published: 2 December 2015 \\ Academic Editor: Maria Emília de Sousa \\ 1 School of Chemical Engineering, Nanjing University of Science and Technology, Nanjing 210094, China; \\ zjr1108@njau.edu.cn \\ 2 Laboratory of Veterinary Pharmacology and Toxicology, College of Veterinary Medicine, \\ Nanjing Agricultural University, Nanjing 210095, China \\ 3 School of Pharmacy, China Pharmaceutical University, Nanjing 210009, China; qz_yao@163.com \\ * Correspondence: Njustlzl723@hotmail.com; Tel./Fax: +86-25-8431-8865 \\ + These authors contributed equally to this work.
}

\begin{abstract}
Tilorone dihydrochloride (1) has great potential for inducing interferon against pathogenic infection. In this paper, we describe a convenient preparation method for 2,7-dihydroxyfluoren-9-one (2), which is a usual pharmaceutical intermediate for preparing tilorone dihydrochloride (1). In the novel method, methyl esterification of 4,4'-dihydroxy-[1,1'-biphenyl]-2-carboxylic acid (4) was carried out under milder conditions with higher yield and played an important role in the preparation of compound 2. The structures of the relative intermediates and target compound were characterized by melting point, IR, MS, and ${ }^{1} \mathrm{H}-\mathrm{NMR}$. Furthermore, the synthesized tilorone dihydrochloride exhibited an obvious effect on induction of interferon- $\alpha$ (IFN- $\alpha$ ) in mice within $12 \mathrm{~h}$, and the peak level was observed until $24 \mathrm{~h}$. This fruitful work has resulted in tilorone dihydrochloride becoming available in large-scale and wide application in clinics, which has a good pharmaceutical development prospects.
\end{abstract}

Keywords: synthesis; 2,7-dihydroxyfluoren-9-one; tilorone; methyl esterification; IFN- $\alpha$

\section{Introduction}

Tilorone dihydrochloride (1, Figure 1) was first reported to have antivirus activity in mice in 1970 [1,2]. Moreover, it has been gradually proved to possess extensive pharmacological functions, such as enhanced phagocytic activity of natural killer cells [3], anti-pyretic [4], anti-fibrotic [5], anti-inflammatory [6-10], anti-virus [11,12], anti-tumor [13-15], as well as interferon induction [16-18]. All the effects are attributed to its planar structure of a modification of the fluorenone skeleton and amino side chain [15,19-21]. The skeleton comes straight from 2,7-dihydroxyfluoren-9-one (2, Figure 1), which can be substituted by appropriate dialkylaminoalkyl halides to give tilorone and other compounds [15]. Compound 2 has been maturely synthesized by $9 H$-fluorene (3) in several steps as outlined in Scheme 1 [22-24]. However, the straight cyclization in the last step is hardly carried out by a solid-solid reaction, which will be not suitable for manufacture on a large scale. Meanwhile, a temperature higher than $200^{\circ} \mathrm{C}$ is required, resulting in low purity, a great deal of energy consumption, a tendency to get out of control to burst, and the yield of pure compound $\mathbf{2}$ is not over $80 \%$. Therefore, there is still a strong demand for developing a more effective approach to produce the intermediate for tilorone under milder conditions. 

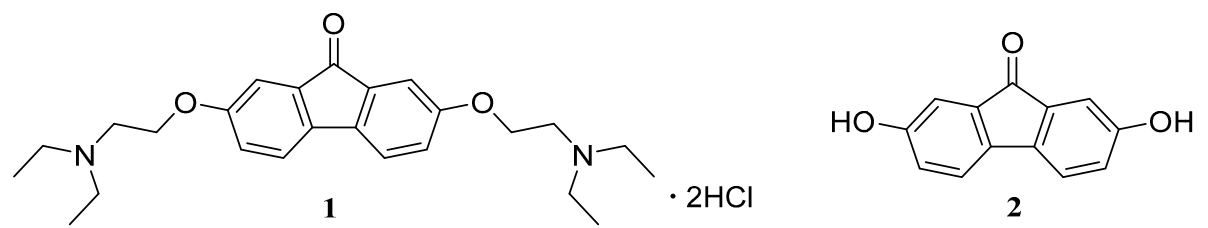

Figure 1. Structures of tilorone dihydrochloride (1) and 2,7-dihydroxyfluoren-9-one (2).

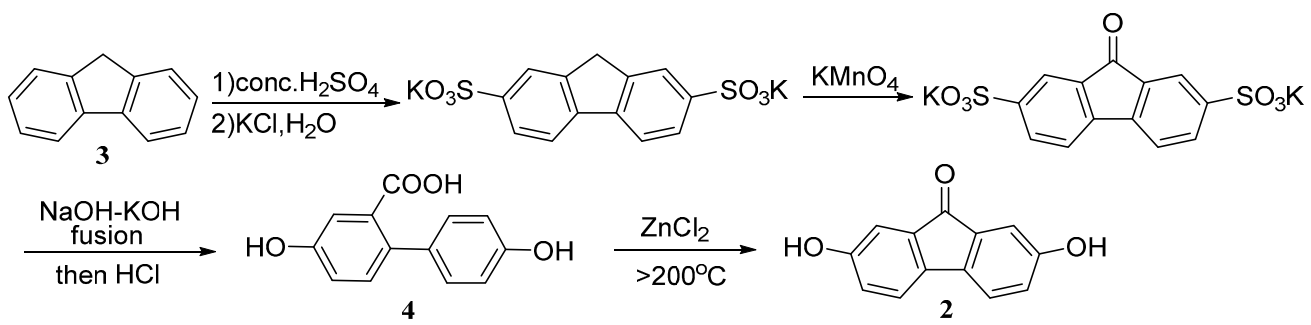

Scheme 1. Traditional synthetic route of 2,7-dihydroxyfluoren-9-one (2).

The antiviral effect of tilorone has been extensively investigated. Many studies had demonstrated the broad-spectrum antiviral activity of tilorone, which performed well with both oral administration and intravenous injection $[1,25]$. Additionally, some other studies had proved that the antiviral property was attributed to the induction of interferon in serum against viral infection. In addition, they also described the method of interferon assay-the plaque reduction assay measured as $\mathrm{U} / \mathrm{mL}$ [16] - but it was not simple and was time-consuming. To improve the efficiency, rapid and accurate detections of interferon measured as $\mathrm{pg} / \mathrm{mL}$ or $\mathrm{ppm}$ need to be developed and play an important role, especially the enzyme-linked immunosorbent assay (ELISA), which is most commonly used in the determination of different antigens, antibodies, cytokines, etc. [26-28].

In the present study, we successfully prepared tilorone dihydrochloride (1) via improving the traditional method in great yield. In contrast, we creatively employed methanol to synthesize ester so that we could obtain purer intermediate in a larger number with a low cost, which was suitable for industrial production. We also carried out an ELISA test to investigate the specific induction of IFN- $\alpha$ by the synthesized tilorone dihydrochloride to analyze kinetic features.

\section{Results and Discussion}

\subsection{Synthesis of Tilorone Dihydrochloride}

As shown in Scheme 2, the target compound 1 was prepared from 2. According to the method of Andrews [22], 4,4'-dihydroxy-[1,1'-biphenyl]-2-carboxylic acid (4) was synthesized by the reaction of 3 in the same reaction conditions shown in Scheme 1. By examining the reaction behavior of compound 4 and $\mathrm{ZnCl}_{2}$ (Scheme 1), we found that compound 4 could not be fully mixed with $\mathrm{ZnCl}_{2}$ and converted into 2 at $200{ }^{\circ} \mathrm{C}$, especially when the reaction scale was large. To solve the problem, we added polyphosphoric acid (PPA) in the reactants to try to make the mixture more easily, but failed. Problems still existed, including inconvenient practice and the existence of heavy material clashing due to the high temperature. In order to improve the efficiency and practicability of this reaction, we found out the following useful method. Compound 4 was firstly esterified in $\mathrm{CH}_{3} \mathrm{OH}$ using concentrated $\mathrm{H}_{2} \mathrm{SO}_{4}$ as a catalyzer under reflux for $2 \mathrm{~h}$, whereby the yield of corresponding methyl ester 5 reached $98 \%$. Then, the conversion of 5 to 2 was successfully accomplished by treatment with $\mathrm{ZnCl}_{2}$ and PPA at $110-120^{\circ} \mathrm{C}$ in $96 \%$ yield, which reduced the temperature and improved the yield to a great degree in contrast to the direct cyclization of 4 . Finally, compound $\mathbf{2}$ was reacted with 2-diethylaminoethylchloride hydrochloride in toluene in the presence of $\mathrm{KOH}$ under reflux for $24 \mathrm{~h}$ to give 6 , which was subsequently acidified to afford 1 . In this synthetic route of compound 1 using compound 3 as a starting material, the overall yield of $\mathbf{1}$ achieved $60 \%$. 

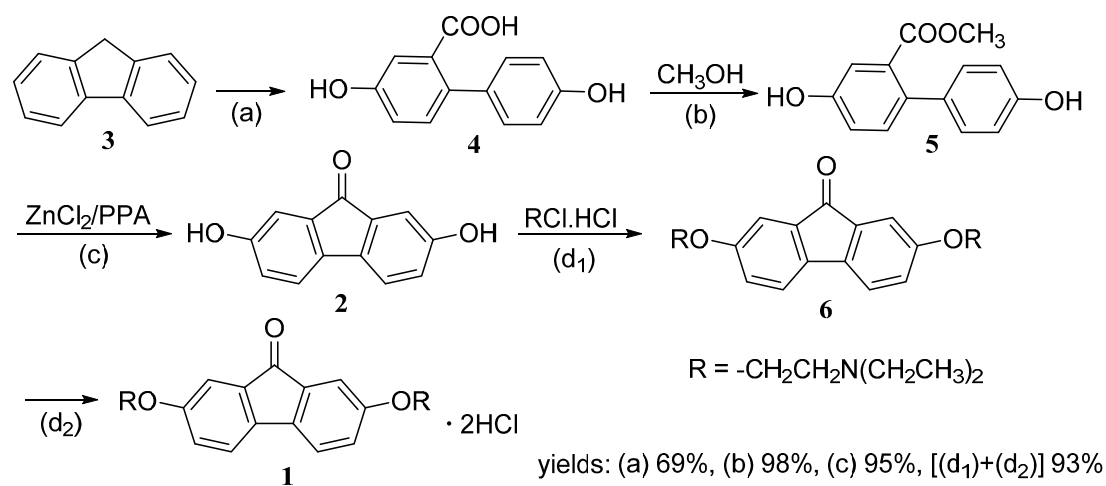

Scheme 2. Approach to 2,7-dihydroxyfluoren-9-one (2) and tilorone dihydrochloride (1).

\subsection{Evaluation on Induction Activity of IFN- $\alpha$}

Tilorone dihydrochloride has shown obvious IFN-inducing and antiviral properties. In the present study, our target compound was dissolved in phosphate buffer solution (PBS) at a concentration permitting an inoculum of $250 \mathrm{mg} / \mathrm{kg}$ in specific pathogen free (SPF) mice orally. Mice were bled eight times after tilorone dihydrochloride challenge and serum was collected and diluted for determination. The data suggests that tilorone dihydrochloride stimulates a delayed but prolonged response with the probable peak levels, approximately $2000 \mathrm{pg} / \mathrm{mL}$, being observed 12 to $24 \mathrm{~h}$ after gavages (Figure 2). The kinetics displayed were similar with variations of the antiviral property.

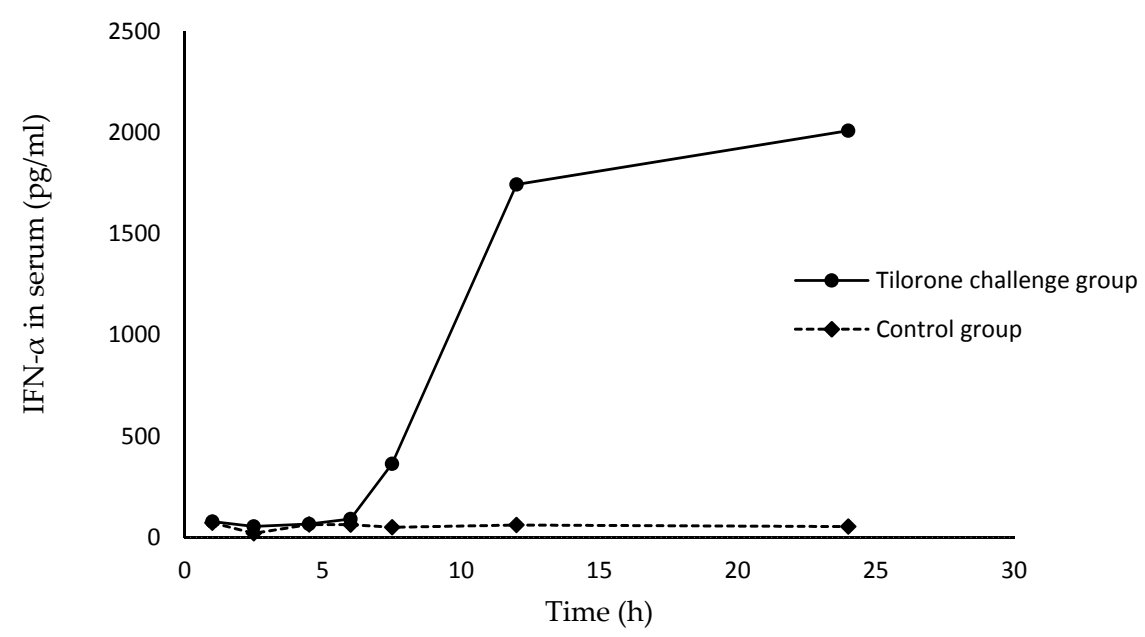

Figure 2. Serum IFN- $\alpha$ response of mice to tilorone dihydrochloride (1).

\section{Experimental Section}

\subsection{Synthesis of Tilorone Dihydrochloride (1)}

\section{General}

Every reaction was monitored, and the endpoint of the reaction was checked by TLC performed on GF-254 silica gel plates with visualization by UV light. Melting points were measured on an YRT-3 temperature apparatus (Tianjin Jing Tuo instrument technology, Tianjin, China) and uncorrected. IR spectra were performed on a IR spectra were recorded on a VERTEX 80 instrument (Bruker Corporation (Beijing, China). Mass spectra were determined on a VG Auto Spec-3000 spectrometer (VG instruments, Kuala Lumpur, Malaysia) and reported as $m / z$. The ${ }^{1} \mathrm{H}-\mathrm{NMR}$ spectral data were recorded on a Bruker Avance 400 NMR spectrometer (Bruker Corporation (Beijing), Beijing, China) and chemical shifts were reported in ppm $(\delta)$ relative to TMS as an internal standard. 
4,4'-dihydroxy-[1,1'-biphenyl]-2-carboxylic acid (4). Compound 3 (200 g, $1.20 \mathrm{~mol})$ was dissolved in concentrated $\mathrm{H}_{2} \mathrm{SO}_{4}(570 \mathrm{~mL})$ at $110-115^{\circ} \mathrm{C}$. After $2 \mathrm{~h}$ of vigorous stirring, the solution was allowed to cool and water $(1.7 \mathrm{~L})$ was added. Then the solution was filtered. To the filtrate $\mathrm{KCl}(400 \mathrm{~g})$ was added and the solution was stirred at room temperature for $30 \mathrm{~min}$. Then the precipitate was filtered and dried to give a solid ( $396 \mathrm{~g}, 82 \%$ ), which was added in batches to a stirred solution of $\mathrm{KMnO}_{4}$ $(208 \mathrm{~g}, 1.32 \mathrm{~mol})$ in water $(7.1 \mathrm{~L})$, maintained at $20-30^{\circ} \mathrm{C}$ for $2 \mathrm{~h}$, and then filtered. The filtrate was concentrated in vacuum to $4.5 \mathrm{~L}$, and cooled to $5^{\circ} \mathrm{C}$. The precipitate was filtered and dried to obtain a solid $(378 \mathrm{~g}, 89 \%), 105 \mathrm{~g}$ of which $(0.24 \mathrm{~mol})$ was added to a mixture of $\mathrm{NaOH}(210 \mathrm{~g}, 5.25 \mathrm{~mol})$ and $\mathrm{KOH}(56 \mathrm{~g}, 1.00 \mathrm{~mol})$. After $1 \mathrm{~h}$ of stirring at $270-300{ }^{\circ} \mathrm{C}$, the melt was allowed to cool and dissolved in water $(1.5 \mathrm{~L})$. The solution was acidified by addition of concentrated $\mathrm{HCl}$ to $\mathrm{pH} 3.0$, and then the precipitate was filtered and dried. Compound 4 was obtained $(52 \mathrm{~g}, 95 \%)$ in an overall yield of $69 \%$; m.p. $269-270{ }^{\circ} \mathrm{C}$ (Lit. $270-273{ }^{\circ} \mathrm{C}$ [22]); IR (KBr), $v\left(\mathrm{~cm}^{-1}\right)$ : 3145.4-2491.3 (OH), 1693.3 (C=O); ESI-MS $(m / z): 229.0[\mathrm{M}-\mathrm{H}]^{-}, \mathrm{C}_{13} \mathrm{H}_{10} \mathrm{O}_{4}(\mathrm{MW} .=230.1) ;{ }^{1} \mathrm{H}-\mathrm{NMR}\left(400 \mathrm{MHz}, \mathrm{DMSO}-d_{6}\right), \delta(\mathrm{ppm}): 12.60(\mathrm{br}$, $1 \mathrm{H}), 9.73(\mathrm{~s}, 1 \mathrm{H}), 9.40(\mathrm{~s}, 1 \mathrm{H}), 7.37(\mathrm{~d}, J=8.5 \mathrm{~Hz}, 1 \mathrm{H}), 7.13(\mathrm{~d}, J=8.4 \mathrm{~Hz}, 1 \mathrm{H}), 7.06(\mathrm{~d}, J=8.4 \mathrm{~Hz}, 2 \mathrm{H})$, $7.03(\mathrm{~d}, J=2.5 \mathrm{~Hz}, 1 \mathrm{H}), 6.91(\mathrm{dd}, J=8.3,2.5 \mathrm{~Hz}, 1 \mathrm{H}), 6.74(\mathrm{~d}, J=8.4 \mathrm{~Hz}, 2 \mathrm{H})$.

Methyl 4,4'-Dihydroxy-[1,1'-biphenyl]-2-carboxylic acid (5). A mixture of 4 (50 g, $0.22 \mathrm{~mol})$, concentrated $\mathrm{H}_{2} \mathrm{SO}_{4}(5 \mathrm{~mL})$, and $\mathrm{CH}_{3} \mathrm{OH}(400 \mathrm{~mL})$ was refluxed for $2 \mathrm{~h}$ and then cooled to r.t., precipitated. The precipitate was filtered and dried to give $5(52 \mathrm{~g}, 98 \%)$; m.p. $224-226^{\circ} \mathrm{C}$; $\mathrm{IR}(\mathrm{KBr}), v\left(\mathrm{~cm}^{-1}\right)$ : 3291.0, $3202.8(\mathrm{OH}) 1692.5(\mathrm{C}=\mathrm{O}), 1435.5\left(\mathrm{CH}_{3}\right)$; ESI-MS $(\mathrm{m} / z): 245.0\left[\mathrm{M}+\mathrm{H}^{+}, \mathrm{C}_{14} \mathrm{H}_{12} \mathrm{O}_{4}(\mathrm{MW} .=244.1)\right.$; ${ }^{1} \mathrm{H}-\mathrm{NMR}\left(400 \mathrm{MHz}, \mathrm{DMSO}-d_{6}\right), \delta(\mathrm{ppm}): 9.80(\mathrm{~s}, 1 \mathrm{H}), 9.42(\mathrm{~s}, 1 \mathrm{H}), 7.18(\mathrm{~d}, J=8.3 \mathrm{~Hz}, 1 \mathrm{H}), 7.02(\mathrm{~d}$, $J=2.0 \mathrm{~Hz}, 2 \mathrm{H}), 7.00(\mathrm{~d}, J=2.0 \mathrm{~Hz}, 1 \mathrm{H}), 6.95(\mathrm{dd}, J=8.4,2.6 \mathrm{~Hz}, 1 \mathrm{H}), 6.76(\mathrm{~d}, J=2.0 \mathrm{~Hz}, 1 \mathrm{H}), 6.75(\mathrm{~d}$, $J=2.0 \mathrm{~Hz}, 1 \mathrm{H}), 3.58(\mathrm{~s}, 3 \mathrm{H})$.

2,7-Dihydroxy-9H-fluoren-9-one (2). A mixture of 5 (50 g, $0.20 \mathrm{~mol}), \mathrm{ZnCl}_{2}$ (50 g, $0.37 \mathrm{~mol}$ ), PPA (33 mL) was stirred at $110-120{ }^{\circ} \mathrm{C}$ for $2 \mathrm{~h}$ and then cooled to r.t., precipitated by addition of water $(500 \mathrm{~mL})$. The precipitate was filtered and dried to obtain $40 \mathrm{~g}$ red-brown crystallized powder (2). Yield 95\%; m.p. 336-337 ${ }^{\circ} \mathrm{C}$ (Lit. $338^{\circ} \mathrm{C}$ [24]); IR (KBr), $v\left(\mathrm{~cm}^{-1}\right)$ : 3388.9, $3360.6(\mathrm{OH}), 1700.7(\mathrm{C}=\mathrm{O})$; ESI-MS $(\mathrm{m} / \mathrm{z})$ : $211.0[\mathrm{M}-\mathrm{H}]^{-}, \mathrm{C}_{13} \mathrm{H}_{8} \mathrm{O}_{3}(\mathrm{MW} .=212.0) ;{ }^{1} \mathrm{H}-\mathrm{NMR}\left(300 \mathrm{MHz}, \mathrm{DMSO}-d_{6}\right), \delta(\mathrm{ppm}): 9.89(\mathrm{~s}, 2 \mathrm{H}), 7.37(\mathrm{~d}$, $J=4.8 \mathrm{~Hz}, 2 \mathrm{H}), 6.90(\mathrm{dd}, J=4.9,2.4 \mathrm{~Hz}, 2 \mathrm{H}), 6.86(\mathrm{~d}, J=2.4 \mathrm{~Hz}, 2 \mathrm{H})$.

2,7-bis[2-(Diethylamino)ethoxy]-9H-fluoren-9-one hydrochloride (1). A mixture of 2 (100 g, $0.47 \mathrm{~mol})$, 2-diethylaminoethylchloride hydrochloride (300 g, $1.74 \mathrm{~mol}), \mathrm{KOH}$ (225 g, $4.01 \mathrm{~mol})$, water (320 mL) and toluene $(1.5 \mathrm{~L})$ was refluxed for $24 \mathrm{~h}$. The emulsion was cooled, and then organic layer was separated, washed with $\mathrm{KOH}$ aq. $(3 \mathrm{~mol} / \mathrm{L}, 500 \mathrm{~mL}$ ) and concentrated up to dryness in vacuum. The residue was dissolved in anhydrous ethanol $(420 \mathrm{~g})$ and acidified with gasified $\mathrm{HCl}$ to $\mathrm{pH}$ 3.0. The orange product was recrystallized with ethanol, filtered, and dried to give $200 \mathrm{~g}$ of compound $\mathbf{1}$ in a yield of $93 \%$; m.p. $231-233{ }^{\circ} \mathrm{C}$ (Lit. $235-236{ }^{\circ} \mathrm{C}$ [22]); IR (KBr), $v\left(\mathrm{~cm}^{-1}\right)$ : 2943.3, $2596.5(\mathrm{CH}), 1708.9$ $(\mathrm{C}=\mathrm{O})$; ESI-MS $(\mathrm{m} / \mathrm{z}): 411.0[\mathrm{M}+\mathrm{H}]^{+}, \mathrm{C}_{25} \mathrm{H}_{34} \mathrm{~N}_{2} \mathrm{O}_{3}$ (MW. $\left.=410.3\right) ;{ }^{1} \mathrm{H}-\mathrm{NMR}\left(400 \mathrm{MHz}, \mathrm{D}_{2} \mathrm{O}\right), \delta(\mathrm{ppm})$ : $7.12(\mathrm{~d}, J=6.5 \mathrm{~Hz}, 2 \mathrm{H}), 6.99(\mathrm{dd}, J=6.5,1.6 \mathrm{~Hz}, 2 \mathrm{H}), 6.89(\mathrm{~d}, J=1.6 \mathrm{~Hz}, 2 \mathrm{H}), 4.39(\mathrm{t}, J=3.6 \mathrm{~Hz}, 4 \mathrm{H}), 3.68$ $(\mathrm{t}, J=3.6 \mathrm{~Hz}, 4 \mathrm{H}), 3.42(\mathrm{q}, J=5.6 \mathrm{~Hz}, 8 \mathrm{H}), 1.44(\mathrm{t}, J=5.8 \mathrm{~Hz}, 12 \mathrm{H})$.

\subsection{Determination of Serum IFN- $\alpha$ Induced by Tilorone Dihydrochloride by ELISA}

SPF mice were housed under conditions of constant temperature and a 12-h light cycle, with food and water provided ad libitum in the Animal Experimental Center, Nanjing Agricultural University. Interferon levels were recorded on a Thermo Multiskan Ascent enzyme-labeled instrument (Thermo Fisher Scientific (Beijing, China). After tilorone dihydrochloride challenge, mice were alive just like the control group, with normal activity levels, appetite, and growth. Sample serum diluent and different concentrations of the standard were added to a micro-well plate (96 tests), which was put at $37^{\circ} \mathrm{C}$ for $2 \mathrm{~h}$. Biotin-conjugate diluent prepared before $30 \mathrm{~min}$ was added after dumping the liquid out of the plate, which would be put at $37^{\circ} \mathrm{C}$ for another $1 \mathrm{~h}$. The plate was washed five times after dumping the liquid and Streptavidin-HRP diluent prepared beforehand was added to the plate that would be 
put in the thermostat again for $1 \mathrm{~h}$ with no light. Substrate solution was added for a 20 min reaction after washing the plate five times. Straight after that stop solution was added to the plate, which was immediately detected for OD450 values.

\section{Conclusions}

We successfully synthesized tilorone dihydrochloride (1) in a great overall yield of $60 \%$. During the reactions, the creative methyl esterification process made the conversion from $\mathbf{5}$ to $\mathbf{2}$ much more easily accomplished and it was operated under much milder conditions (acquired temperature reduced from $200{ }^{\circ} \mathrm{C}$ to $110-120^{\circ} \mathrm{C}$ ), whereby the 2 produced was of higher purity and in greater yield so that tilorone dihydrochloride of better quality might be obtained. On the other hand, the synthesized tilorone dihydrochloride exhibited the significant property of inducing a delayed but prolonged interferon response in mice. In summary, esterification can be a good choice for preparing an intermediate of tilorone dihydrochloride, which can be an effective medicine for clinical applications.

Acknowledgments: We are thankful for the valuable comments from Dawei Guo, Nanjing Agricultural University. This work was supported by the grant from the Natural Science Foundation of Jiangsu Province in China (BK20140716).

Author Contributions: Zuliang Liu initiated and led the project. Junren Zhang performed the experiments. Qizheng Yao analyzed the data. Junren Zhang wrote the manuscript. The manuscript was finalized through contributions from all authors, and all authors approved the final manuscript.

Conflicts of Interest: The authors declare no conflict of interest.

\section{References}

1. Krueger, R.E.; Mayer, G.D. Tilorone hydrochloride: An orally active antiviral agent. Science 1970, 169, 1213-1214. [CrossRef] [PubMed]

2. Krueger, R.F.; Mayer, G.D.; Yoshimura, S.; Ludwig, K.A. In vivo evaluations of tilorone hydrochloride against semliki forest virus. Antimicrob. Agents Chemother. 1970, 10, 486-490. [PubMed]

3. Gaforio, J.J.; Ortega, E.; Algarra, I.; Serrano, M.J.; Alvarez de Cienfuegos, G. Nk cells mediate increase of phagocytic activity but not of proinflammatory cytokine (interleukin-6 [IL-6], tumor necrosis factor alpha, and IL-12) production elicited in splenic macrophages by tilorone treatment of mice during acute systemic candidiasis. Clin. Vaccine Immunol. 2002, 9, 1282-1294. [CrossRef]

4. Clark, W.G.; Robins, J.A. The antipyretic effect of tilorone hydrochloride in the cat. Br. J. Pharmacol. 1978, 62, 281-287. [CrossRef] [PubMed]

5. Lepparanta, O.; Tikkanen, J.M.; Bespalov, M.M.; Koli, K.; Myllarniemi, M. Bone morphogenetic protein-inducer tilorone identified by high-throughput screening is antifibrotic in vivo. Am. J. Respir. Cell Mol. Biol. 2013, 48, 448-455. [CrossRef] [PubMed]

6. Megel, H.; Raychaudhuri, A.; Shemano, I.; Beaver, T.H.; Thomas, L.L. The anti-inflammatory actions of tilorone hydrochloride. Proc. Soc. Exp. Biol. Med. 1975, 149, 89-93. [CrossRef] [PubMed]

7. Kovarik, P.; Sauer, I.; Schaljo, B. Molecular mechanisms of the anti-inflammatory functions of interferons. Immunobiology 2007, 212, 895-901. [CrossRef] [PubMed]

8. Skrots'ka, O.I.; Zholobak, N.M.; Antonenko, S.V.; Spivak, M.; Karpov, O.V. Antiherpetic effect of rna-tilorone molecular complex in cell culture. Mikrobiol. Z. 2007, 69, 62-68. [PubMed]

9. Zholobak, N.M.; Kavok, N.S.; Bogorad-Kobelska, O.S.; Borovoy, I.A.; Malyukina, M.Y.; Spivak, M.Y. Effect of tilorone and its analogues on the change of mitochondrial potential of rat hepatocytes. Fiziolohichnyi Zhurnal 2012, 58, 39-43. [CrossRef] [PubMed]

10. Briggs, C.A.; Schrimpf, M.R.; Anderson, D.J.; Gubbins, E.J.; Gronlien, J.H.; Hakerud, M.; Ween, H.; Thorin-Hagene, K.; Malysz, J.; Li, J.; et al. Alpha7 nicotinic acetylcholine receptor agonist properties of tilorone and related tricyclic analogues. Br. J. Pharmacol. 2008, 153, 1054-1061. [CrossRef] [PubMed]

11. Karpov, A.V.; Zholobak, N.M.; Spivak, N.Y.; Rybalko, S.L.; Antonenko, S.V.; Krivokhatskaya, L.D. Virus-inhibitory effect of a yeast RNA-tilorone molecular complex in cell cultures. Acta Virol. 2001, 45, 181-184. [PubMed] 
12. Karpov, A.V.; Antonenko, S.V.; Barbasheva, E.V.; Spivak, N. Study of anti-HIV activity of the yeast RNA-tilorone molecular complex. Vopr. Virusol. 1997, 42, 17-19. [PubMed]

13. Wissing, M.D.; Dadon, T.; Kim, E.; Piontek, K.B.; Shim, J.S.; Kaelber, N.S.; Liu, J.O.; Kachhap, S.K.; Nelkin, B.D. Small-molecule screening of pc3 prostate cancer cells identifies tilorone dihydrochloride to selectively inhibit cell growth based on cyclin-dependent kinase 5 expression. Oncol. Rep. 2014, 32, 419-424. [CrossRef] [PubMed]

14. Algarra, I.; Perez, M.; Hoglund, P.; Gaforio, J.J.; Ljunggren, H.G.; Garrido, F. Generation and control of metastasis in experimental tumor systems; inhibition of experimental metastases by a tilorone analogue. Int. J. Cancer 1993, 54, 518-523. [CrossRef] [PubMed]

15. Zhou, D.; Tuo, W.; Hu, H.; Xu, J.; Chen, H.; Rao, Z.; Xiao, Y.; Hu, X.; Liu, P. Synthesis and activity evaluation of tilorone analogs as potential anticancer agents. Eur. J. Med. Chem. 2013, 64, 432-441. [CrossRef] [PubMed]

16. Li, L.; Sherry, B. Ifn-alpha expression and antiviral effects are subtype and cell type specific in the cardiac response to viral infection. Virology 2010, 396, 59-68. [CrossRef] [PubMed]

17. Hiyama, Y.; Kuriyama, K. Dissociation between antiinflammatory action of tilorone and its interferon inducing activity. Agents Actions 1991, 33, 229-232. [CrossRef] [PubMed]

18. Hofmann, H.; Kunz, C. The protective effect of the interferon inducers tilorone hydrochloride and poly i:C on experimental tick-borne encephalitis in mice. Arch. Gesamte Virusforsch. 1972, 37, 262-266. [CrossRef] [PubMed]

19. Lee, C.C.; Chang, D.M.; Huang, K.F.; Chen, C.L.; Chen, T.C.; Lo, Y.; Guh, J.H.; Huang, H.S. Design, synthesis and antiproliferative evaluation of fluorenone analogs with DNA topoisomerase i inhibitory properties. Bioorg. Med. Chem. 2013, 21, 7125-7133. [CrossRef] [PubMed]

20. Cinelli, M.A.; Morrell, A.; Dexheimer, T.S.; Scher, E.S.; Pommier, Y.; Cushman, M. Design, synthesis, and biological evaluation of 14-substituted aromathecins as topoisomerase i inhibitors. J. Med. Chem. 2008, 51, 4609-4619. [CrossRef] [PubMed]

21. Waldo, J.P.; Zhang, X.; Shi, F.; Larock, R.C. Efficient synthesis of fluoren-9-ones by the palladium-catalyzed annulation of arynes by 2-haloarenecarboxaldehydes. J. Org. Chem. 2008, 73, 6679-6685. [CrossRef] [PubMed]

22. Andrews, E.R.; Fleming, R.W.; Grisar, J.M.; Kihm, J.C.; Wenstrup, D.L.; Mayer, G.D. Bis-basic-substituted polycyclic aromatic compounds. A new class of antiviral agents. 2. Tilorone and related bis-basic ethers of fluorenone, fluorenol, and fluorene. J. Med. Chem. 1974, 17, 882-886. [CrossRef] [PubMed]

23. Burke, H.M.; Joullie, M.M. New synthetic routes to tilorone dihydrochloride and some of its analogues. J. Med. Chem. 1978, 21, 1084-1086. [CrossRef] [PubMed]

24. Agrawal, K.C. Fluorene derivatives for antitumor activity. J. Med. Chem. 1967, 10, 99-101. [CrossRef] [PubMed]

25. Balezina, T.I.; Korneeva, L.E.; Zemskov, V.M.; Loidina, G.I.; Nikolaeva, O.V.; Fainshtein, S.L.; Fadeeva, L.L.; Eromolieva, Z.V. Comparison of interferon-inducing activities and antiviral effects of tobacco mosaic virus, tilorone and sodium nucleinate. Acta Virol. 1977, 21, 338-343. [PubMed]

26. Hane, H.; Muro, Y.; Watanabe, K.; Ogawa, Y.; Sugiura, K.; Akiyama, M. Establishment of an ELISA to detect anti-glycyl-tRNA synthetase antibody (anti-EJ), a serological marker of dermatomyositis/polymyositis and interstitial lung disease. Clin. Chim. Acta 2014, 431, 9-14. [CrossRef] [PubMed]

27. Piccoli, L.; Meroni, V.; Genco, F.; Tamarozzi, F.; Tinelli, C.; Filice, C.; Brunetti, E. Serum cytokine profile by ELISA in patients with echinococcal cysts of the liver: A stage-specific approach to assess their biological activity. Clin. Dev. Immunol. 2012, 2012, 483935. [CrossRef] [PubMed]

28. Rhodes, S.G.; Gruffydd-Jones, T.; Gunn-Moore, D.; Jahans, K. Adaptation of IFN-gamma ELISA and ELISPOT tests for feline tuberculosis. Vet. Immunol. Immunopathol. 2008, 124, 379-384. [CrossRef] [PubMed]

Sample Availability: All the samples of the compounds are available from the authors.

(c) 2015 by the authors; licensee MDPI, Basel, Switzerland. This article is an open access article distributed under the terms and conditions of the Creative Commons by Attribution (CC-BY) license (http:/ / creativecommons.org/licenses/by/4.0/). 